\title{
Pusillimonas harenae sp. nov., isolated from a sandy beach, and emended description of the genus Pusillimonas
}

Correspondence

Che Ok Jeon

cojeon@cau.ac.kr

\author{
Moon Su Park, ${ }^{1 \dagger}$ Youn-Je Park, ${ }^{2 \dagger}$ Ji Young Jung, ${ }^{1}$ Seung Hyeon Lee, ${ }^{1}$ \\ Woojun Park, ${ }^{3}$ Kangseok Lee ${ }^{1}$ and Che Ok Jeon ${ }^{1}$ \\ ${ }^{1}$ Department of Life Science \& Research Center for Biomolecules and Biosystems, \\ Chung-Ang University, Seoul 156-756, Republic of Korea \\ ${ }^{2}$ Department of Applied Bioscience, CHA University, Seoul 135-081, Republic of Korea \\ ${ }^{3}$ Division of Environmental Science and Ecological Engineering, Korea University, Seoul 136-701, \\ Republic of Korea
}

\begin{abstract}
A Gram-stain-negative, motile bacterium with two lateral flagella, designated strain $B 201^{\top}$, was isolated from beach sand from the Taean coast in South Korea. Cells were ovoid rods and positive for catalase and oxidase. Growth of strain $\mathrm{B} 201^{\top}$ was observed between 15 and $45{ }^{\circ} \mathrm{C}$ (optimum, $30{ }^{\circ} \mathrm{C}$ ) and between $\mathrm{pH} 5.0$ and 9.0 (optimum, $\mathrm{pH}$ 6.0-7.5). Strain $\mathrm{B} 201^{\top}$ contained ubiquinone Q-8 as the major isoprenoid quinone, but MK-6 was also present as a minor quinone. The major fatty acids of strain $B 201^{\top}$ were $C_{17: 0}$ cyclo, $C_{16: 0}$, summed feature 2 (iso- $C_{16: 1} 1 / C_{14: 0} 3-O H$ and/or $\left.\mathrm{C}_{12: 0} \mathrm{ALDE}\right), \mathrm{C}_{12: 0}$ and $\mathrm{C}_{19: 0}$ cyclo $\omega 8 \mathrm{c}$. The major cellular polar lipids were phosphatidylglycerol, diphosphatidylglycerol, phosphatidylethanolamine, an unidentified phospholipid and three aminolipids. The genomic DNA G+C content was $53.1 \mathrm{~mol} \%$. Phylogenetic analysis based on 16S rRNA gene sequences showed that the strain formed a phyletic lineage with Pusillimonas ginsengisoli $\mathrm{DCY}^{2} 5^{\top}$ within the genus Pusillimonas. Strain $\mathrm{B} 201^{\top}$ was most closely related to $P$. ginsengisoli $\mathrm{DCY} 25^{\top}$ and Pusillimonas soli $\mathrm{MJO}^{\top}$ with similarities of 98.6 and $97.5 \%$, respectively. However, DNA-DNA relatedness values of strain $\mathrm{B} 201^{\top}$ with $P$. ginsengisoli DCY $25^{\top}$ and $P$. soli $\mathrm{MJ}^{\top} 7^{\top}$ were $30.2 \pm 5.4$ and $4.9 \pm 1.8 \%$, respectively. On the basis of chemotaxonomic data and molecular properties, strain $B 201^{\top}$ represents a novel species of the genus Pusillimonas, for which the name Pusillimonas harenae sp. nov. is proposed; the type strain is $B 201^{\top}\left(=\right.$ KACC $\left.14927^{\top}=J C M 16917^{\top}\right)$. An emended description of the genus Pusillimonas is given.
\end{abstract}

The genus Pusillimonas, a member of the family Alcaligenaceae within the class Betaproteobacteria, was first proposed by Stolz et al. (2005). At the time of writing, the genus comprised only three species with validly published names: Pusillimonas ginsengisoli, Pusillimonas soli and Pusillimonas noertemannii. P. noertemannii $\mathrm{BN}^{\mathrm{T}}$ was isolated from the River Elbe in Germany (Stolz et al., 2005), and $P$. ginsengisoli $\mathrm{DCY} 25^{\mathrm{T}}$ and P. soli $\mathrm{M} 07^{\mathrm{T}}$ were isolated from soil from a ginseng field and a farm, respectively, in South Korea (Lee et al., 2010; Srinivasan et al., 2010), indicating that

TThese authors contributed equally to this work.

Abbreviations: ASW, artificial seawater; DPG, diphosphatidylglycerol; $P E$, phosphatidylethanolamine; PG, phosphatidylglycerol.

The GenBank/EMBL/DDBJ accession number for the 16S rRNA gene sequence of strain $B 201^{\top}$ is GQ232740.

Three supplementary figures are available with the online version of this paper. members of the genus Pusillimonas may have a diverse habitat range. Typical features of the genus Pusillimonas are: the presence of ubiquinone Q-8; $\mathrm{C}_{17: 0}$ cyclo, $\mathrm{C}_{16: 0}$ and $\mathrm{C}_{19: 0}$ cyclo $\omega 8 c$ as major fatty acids; and phosphatidylethanolamine (PE), phosphatidylglycerol (PG) and diphosphatidylglycerol (DPG) as major polar lipids. Coastal seashores are marine habitats that possess valuable biological resources such as micro-organisms and marine animals that play very important roles in the functioning of ecosystems. During a course of studies investigating microbial communities that inhabit coastal seashores, several bacterial community members have been characterized (Kim et al., 2010a, b; Jin et al., 2011; Jung et al., 2011; Lee et al., 2011). Here, the taxonomic characterization of a novel Pusillimonas species isolated from beach sand of the Yellow Sea in South Korea is described.

Strain $\mathrm{B} 201^{\mathrm{T}}$ was isolated from beach sand of the Taean coast ( $\left.36^{\circ} 50^{\prime} 5 \mathrm{~N}^{\prime \prime} 126^{\circ} 09^{\prime} 9^{\prime \prime} \mathrm{E}\right)$ in the Yellow Sea, South Korea, using a previously described procedure with some 
modifications (Kim et al., 2008). Briefly, a soil sample was serially diluted in $0.9 \%(\mathrm{w} / \mathrm{v})$ saline and spread on marine agar 2216 (MA; Difco) plates and incubated under aerobic conditions at $25{ }^{\circ} \mathrm{C}$ for 5 days. Colonies were randomly selected and crude genomic DNA from respective colonies was prepared as described previously ( $\mathrm{Lu}$ et al., 2006). Amplicons were double-digested with HaeII and HhaI. RFLP patterns were analysed on $2.5 \%$ MetaPhore agarose (BioWhittaker) gels; colonies were grouped according to their RFLP patterns and representative PCR products containing distinct RFLP patterns were sequenced. The resulting $16 \mathrm{~S}$ rRNA gene sequences were analysed using the program BLAST (http://www.ncbi.nlm.nih.gov/Blast.cgi/) in GenBank. From the analysis, a novel strain belonging to the genus Pusillimonas, designated strain $\mathrm{B} 201^{\mathrm{T}}$, was selected for further phenotypic and phylogenetic analysis. The strain was grown routinely on R2A agar (Difco) aerobically at $30{ }^{\circ} \mathrm{C}$ for 3 days, except where indicated otherwise. The strain was stored at $-80{ }^{\circ} \mathrm{C}$ in R2A broth supplemented with $10 \%$ (v/v) glycerol. P. ginsengisoli KCTC $22046^{\mathrm{T}}$, P. soli $\mathrm{MJ} 07^{\mathrm{T}}$ and $P$. noertemannii KACC $13183^{\mathrm{T}}$ were used as reference strains for DNA-DNA hybridization, phenotypic characterization and fatty acid analysis; P. ginsengisoli KCTC $22046^{\mathrm{T}}$ was purchased from KCTC (Republic of Korea), and P. soli

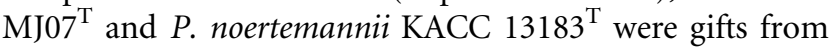
M. Lee (H-Plus Eco, Daejeon, Republic of Korea; Lee et al., 2010) and KACC (Republic of Korea), respectively.

The $16 \mathrm{~S}$ rRNA gene sequence $\left(1400 \mathrm{nt}\right.$ ) of strain $\mathrm{B} 201^{\mathrm{T}}$ was compared with available $16 \mathrm{~S}$ rRNA gene sequences from
GenBank using the program BLAST to determine an approximate phylogenetic affiliation. Sequence similarity values between the isolate and related bacteria were evaluated using the EzTaxon nucleotide similarity search program (http://147. 47.212.35:8080/; Chun et al., 2007) and aligned by using Clustal W (Thompson et al., 1994). Phylogenetic trees were constructed using the neighbour-joining and maximumparsimony algorithms in the PHYLIP software (version 3.6; Felsenstein, 2002). The resulting tree topologies were evaluated using bootstrap analysis based on 1000 resampled datasets with the PHYLIP package. Maximum-likelihood analysis with bootstrap values was performed using RAxML-HPC on Abe (version 7.2.6) of the Cyberinfrastructure for Phylogenetic Research project (CIPRES; www.phylo.org) at the San Diego Supercomputer Center.

Comparative analysis of 16S rRNA gene sequences showed that strain $\mathrm{B} 201^{\mathrm{T}}$ was most closely related to $P$. ginsengisoli $\mathrm{DCY} 25^{\mathrm{T}}$, P. soli $\mathrm{MJ} 07^{\mathrm{T}}$ and $P$. noertemannii $\mathrm{BN}^{\mathrm{T}}$ with similarities of 98.6, 97.5 and $96.9 \%$, respectively. Neighbourjoining phylogenetic analysis based on $16 \mathrm{~S}$ rRNA gene sequences indicated that strain $\mathrm{B} 201^{\mathrm{T}}$ formed a phyletic lineage with $P$. ginsengisoli $\mathrm{DCY} 25^{\mathrm{T}}$ within the genus Pusillimonas with a bootstrap value of $62 \%$ (Fig. 1). Analysis with the maximum-likelihood and maximumparsimony algorithms also indicated that strain $\mathrm{B} 201^{\mathrm{T}}$ formed a phyletic lineage within the genus Pusillimonas (Supplementary Fig. S1, available in IJSEM Online).

DNA-DNA hybridization was carried out to evaluate the level of DNA relatedness of strain $\mathrm{B} 201^{\mathrm{T}}$ with $P$. ginsengisoli

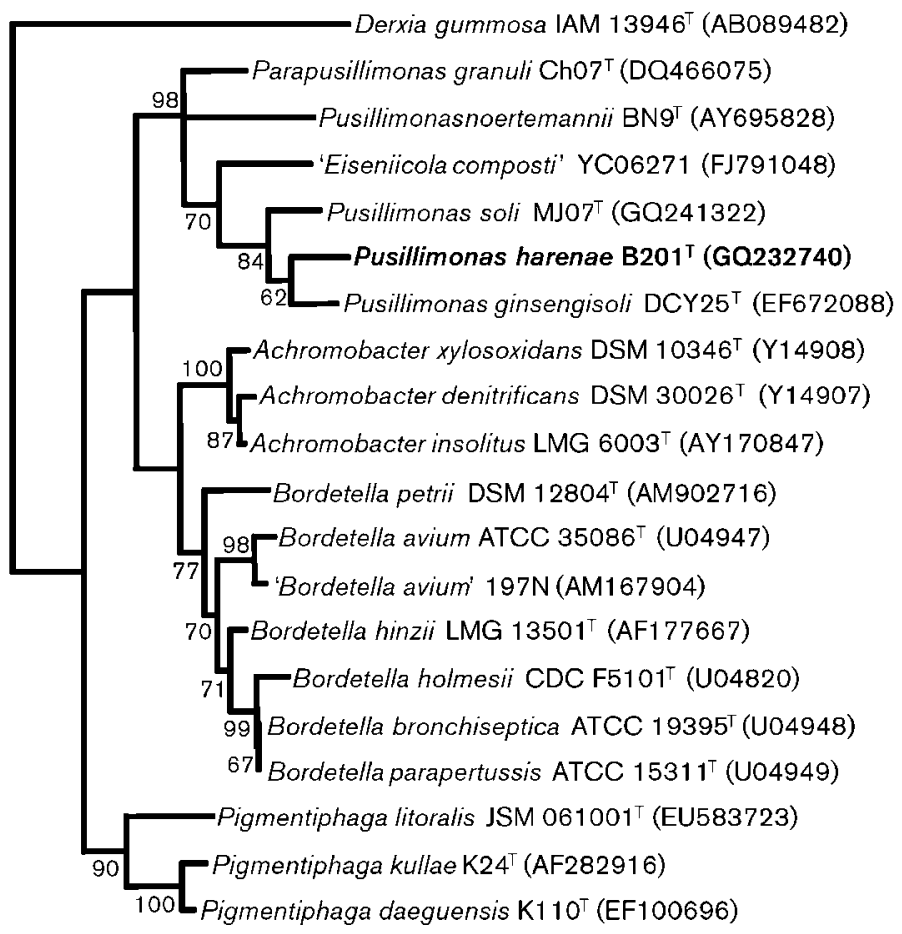

\footnotetext{
Fig. 1. Neighbour-joining tree based on $16 \mathrm{~S}$ rRNA gene sequences showing the phylogenetic relationships of strain $B 201^{\top}$ and related taxa. Bootstrap values (percentages of 1000 replicates) are shown at nodes; only values $>50 \%$ are shown. Derxia gummosa IAM $13946^{\top}$ (AB089482) was used as the outgroup. Bar, 0.01 changes per nucleotide position. Phylogenetic trees built using the maximum-likelihood and maximum-parsimony algorithms are also available as Supplementary Fig. S1 in IJSEM Online.
} 
KCTC $22046^{\mathrm{T}}$ and P. soli $\mathrm{MJ}^{\mathrm{T}} \mathrm{7}^{\mathrm{T}}$, as described previously (Lee et al., 2011). Briefly, extracted genomic DNAs were fragmented with HaeIII and, after denaturation using $\mathrm{NaOH}$ solution and heating $\left(80^{\circ} \mathrm{C}\right)$, various amounts of the fragmented DNA were blotted onto Hybond-N + nylon membranes (Amersham Pharmacia Biotech) (three replicates). Each DNA sample $(4 \mu \mathrm{g})$ was used individually as a labelled DNA probe for cross-hybridization (Park et al., 2007). Random-primed DNA labelling with digoxigenin (DIG)-dUTP and detection of hybrids by enzyme immunoassay on a nylon membrane were performed using the DIG High Prime DNA labelling kit (Roche Applied Science) according to the manufacturer's instructions. Hybridization signals were captured and analysed with Bio-Rad Quantity One software (version 4.62). The signal produced by hybridization of the probes to the homologous target DNAs was taken to be $100 \%$ and signal intensities by self-hybridization of the series of dilutions were used for calculation of the levels of DNA relatedness of strain B201 ${ }^{\mathrm{T}}$ with $P$. ginsengisoli KCTC $22046^{\mathrm{T}}$ and $P$. soli $\mathrm{MJ}^{\mathrm{T}} 7^{\mathrm{T}}$. Hybridization experiments were always confirmed by cross-hybridization. DNA-DNA relatedness values of strain B201 ${ }^{\mathrm{T}}$ with P. ginsengisoli KCTC $22046^{\mathrm{T}}$ and P. soli MJ07 were $30.2 \pm 5.4$ and $4.9 \pm 1.8 \%$, respectively, which are clearly below the $70 \%$ threshold generally accepted for species delineation (Rosselló-Mora \& Amann, 2001).

Growth was tested at $30{ }^{\circ} \mathrm{C}$ on several bacteriological media: R2A agar (Difco), laboratory-prepared LuriaBertani (LB) agar, tryptic soy agar (TSA; Difco) and MA (Difco). Cultivation conditions for strain $\mathrm{B} 201^{\mathrm{T}}$ were examined by growing the isolate on $\mathrm{R} 2 \mathrm{~A}$ agar at $5-55{ }^{\circ} \mathrm{C}$ (at $5{ }^{\circ} \mathrm{C}$ intervals) and in $\mathrm{R} 2 \mathrm{~A}$ broth adjusted to $\mathrm{pH} 4.5$ 11.0 (at $0.5 \mathrm{pH}$ unit intervals). Media with different $\mathrm{pH}$ values were prepared using the appropriate biological buffers (Gomori, 1955): $\mathrm{pH}$ values below 8.0, $\mathrm{Na}_{2} \mathrm{HPO}_{4} /$ $\mathrm{NaH}_{2} \mathrm{PO}_{4}$ buffer; pH 8.0-10.0, $\mathrm{Na}_{2} \mathrm{CO}_{3} / \mathrm{NaHCO}_{3}$ buffer; $\mathrm{pH}$ 11.0, $\mathrm{Na}_{2} \mathrm{HPO}_{4} / \mathrm{NaOH}$ buffer. The $\mathrm{pH}$ values were rechecked after sterilization. Gram staining was performed using the bioMérieux Gram Stain kit according to the instructions of the manufacturer. Cell morphology, motility and the presence of flagella were studied using phase-contrast microscopy (Axio Lab.A1; Carl Zeiss) and transmission electron microscopy (JEM-1010; JEOL) with 2-day-old cells grown on R2A agar as described previously (Jeon et al., 2004). $\mathrm{NaCl}$ requirements and tolerance were determined in nutrient broth (NB: $3.0 \mathrm{~g}$ beef extract and $5.0 \mathrm{~g}$ peptone per litre) supplemented with modified artificial seawater (ASW) containing various amounts of $\mathrm{NaCl}[0-10 \% \quad(\mathrm{w} / \mathrm{v}) \quad \mathrm{NaCl}$ at $1 \%$ intervals, $5.94 \mathrm{~g}$ $\mathrm{MgSO}_{4} \cdot 7 \mathrm{H}_{2} \mathrm{O}, 4.53 \mathrm{~g} \mathrm{MgCl}_{2} \cdot 6 \mathrm{H}_{2} \mathrm{O}, 0.64 \mathrm{~g} \mathrm{KCl}$ and $1.3 \mathrm{~g} \mathrm{CaCl}_{2}$ per litre] (Kahng et al., 2009). Oxidase activity was tested by oxidation of $1 \%(\mathrm{w} / \mathrm{v})$ tetramethyl- $p$ phenylenediamine (Merck) and catalase activity was evaluated by the production of oxygen bubbles in $3 \%$ $(\mathrm{v} / \mathrm{v})$ aqueous hydrogen peroxide solution (Smibert \& Krieg, 1994). Additional enzymic activities and biochemical features were determined using API ZYM and API
20NE kits (bioMérieux) according to the instructions of the manufacturer except that inocula were prepared by suspending cells in $0.85 \%(\mathrm{w} / \mathrm{v}) \mathrm{NaCl}$ solution. Anaerobic growth was assessed on MA under anaerobic (with $4-10 \% \mathrm{CO}_{2}$ ) conditions using the GasPak Plus system (BBL) at $30{ }^{\circ} \mathrm{C}$ for 20 days.

Strain $\mathrm{B} 201^{\mathrm{T}}$ grew well on R2A agar, LB agar, TSA and MA at $30{ }^{\circ} \mathrm{C}$. Growth on R2A agar was slightly faster than on other agar media. When tested on R2A, growth of strain $\mathrm{B} 201^{\mathrm{T}}$ was observed at $15-45^{\circ} \mathrm{C}$ and $\mathrm{pH}$ 5.0-9.0, with optimum growth at $30{ }^{\circ} \mathrm{C}$ and $\mathrm{pH}$ 6.0-7.5. Strain $\mathrm{B} 201^{\mathrm{T}}$ grew in NB supplemented with modified ASW containing $0-6 \%(\mathrm{w} / \mathrm{v}) \mathrm{NaCl}$; optimal growth occurred in $0-3 \%$ $\mathrm{NaCl}$. Bacterial cells were Gram-negative, strictly aerobic, ovoid rods, $0.5-0.7 \mu \mathrm{m}$ wide and $0.6-0.9 \mu \mathrm{m}$ long, and motile by means of two lateral flagella on one side (Supplementary Fig. S2, available in IJSEM Online); motility clearly differentiated strain $\mathrm{B} 201^{\mathrm{T}}$ from $P$. ginsengisoli DCY $25^{\mathrm{T}}$. Physiological and biochemical characteristics of strain $\mathrm{B} 201^{\mathrm{T}}$ are shown in Table 1 and the species description. Some characteristics are in accordance with those of members of the genus Pusillimonas, whereas others allow strain $\mathrm{B} 201^{\mathrm{T}}$ to be differentiated from other Pusillimonas species.

Isoprenoid quinones were analysed using HPLC (model LC-20A; Shimadzu) equipped with a diode array detector (SPD-M20A; Shimadzu) and a reversed-phase column $(250 \times 4.6 \mathrm{~mm}$, Kromasil; Akzo Nobel) as described previously (Komagata \& Suzuki, 1987). For analysis of fatty acid methyl esters, cells of strain $\mathrm{B} 201^{\mathrm{T}}$ and reference strains (P. ginsengisoli KCTC $22046^{\mathrm{T}}$ and $P$. noertemannii KACC $13183^{\mathrm{T}}$ ) were harvested from R2A agar plates after incubation at $30{ }^{\circ} \mathrm{C}$ for 3 days. Analysis of fatty acid methyl esters was carried out according to the instructions of the Sherlock Microbial Identification System (MIDI; Microbial ID, Inc.). Polar lipids were determined by TLC as described by Minnikin et al. (1977). The DNA G $+\mathrm{C}$ content of strain $\mathrm{B} 201^{\mathrm{T}}$ was determined using HPLC fitted with a reversedphase column (GROM-SIL 100 ODS-2FE; GROM) according to the method of Tamaoka \& Komagata (1984). The major respiratory lipoquinone detected in strain $\mathrm{B} 201^{\mathrm{T}}$ was ubiquinone Q-8, at a peak area ratio of approximately 85$87 \%$; a minor amount of menaquinone MK-6 was also present (peak area ratio of approximately $13-15 \%$ ). The major cellular fatty acids ( $>5 \%$ of the total fatty acids) were $\mathrm{C}_{17: 0}$ cyclo (35.65\%), $\mathrm{C}_{16: 0}(32.12 \%)$, summed feature 2 (iso- $\mathrm{C}_{16: 1} \mathrm{I} / \mathrm{C}_{14: 0} 3-\mathrm{OH}$ and/or $\mathrm{C}_{12: 0}$ ALDE; $8.77 \%$ ), $\mathrm{C}_{12: 0}$ $(7.87 \%)$ and $\mathrm{C}_{19: 0}$ cyclo $\omega 8 c(5.98 \%)$. Although the overall fatty acid profile of strain $\mathrm{B} 201^{\mathrm{T}}$ was similar to those of other Pusillimonas species, differences in the amounts of various fatty acids distinguished the novel isolate from other Pusillimonas species (Table 2). The major polar lipids were PG, DPG, PE, three aminolipids and an unidentified phospholipid (Supplementary Fig. S3, available in IJSEM Online); this polar lipid profile was generally in accordance with those of other Pusillimonas species (Stolz et al., 2005; Srinivasan et al., 2010). The DNA G + C content of strain 
Table 1. Phenotypic characteristics of strain $\mathrm{B} 201^{\top}$ and related Pusillimonas species

Strains: 1, strain $\mathrm{B} 201^{\mathrm{T}} ; 2$, P. ginsengisoli KCTC $22046^{\mathrm{T}}$ (Srinivasan et al., 2010); 3, P. noertemannii KACC $13183^{\mathrm{T}}$ (Stolz et al., 2005); 4, P. soli MJ07 ${ }^{\mathrm{T}}$ (Lee et al., 2010). All strains are positive for the following: esterase (C4), esterase lipase (C8), leucine arylamidase, valine arylamidase and acid phosphatase (API ZYM); oxidase; and growth in $0 \%(\mathrm{w} / \mathrm{v}) \mathrm{NaCl}$. All strains are negative for: $\alpha$-galactosidase, $\beta$-galactosidase, $\beta$-glucuronidase, $\alpha$-glucosidase, $\beta$-glucosidase, $N$-acetyl- $\beta$-glucosaminidase, $\alpha$-mannosidase and $\alpha$-fucosidase (API ZYM); Gram staining; growth at $4{ }^{\circ} \mathrm{C}$; and hydrolysis of gelatin. + , Positive; - , negative; $(+)$, weakly positive.

\begin{tabular}{|c|c|c|c|c|}
\hline Characteristic & $1^{\star}$ & 2 & 3 & 4 \\
\hline Morphology & Ovoid rods & Short rods & Rods & Rods \\
\hline Colony colour & Ivory & Pale yellow & Brownish & Yellow \\
\hline \multicolumn{5}{|l|}{ Growth at/in: } \\
\hline $42{ }^{\circ} \mathrm{C}$ & + & - & + & - \\
\hline $5 \% \mathrm{NaCl}^{*}$ & + & + & - & + \\
\hline Hydrolysis of urea* & + & - & - & - \\
\hline \multicolumn{5}{|l|}{ Enzyme activity (API ZYM)* } \\
\hline Alkaline phosphatase & $(+)$ & + & + & + \\
\hline Lipase (C14) & - & $(+)$ & + & - \\
\hline Cystine arylamidase & + & + & $(+)$ & - \\
\hline Trypsin & $(+)$ & + & $(+)$ & - \\
\hline$\alpha$-Chymotrypsin & $(+)$ & $(+)$ & + & + \\
\hline $\begin{array}{l}\text { Naphthol-AS-BI- } \\
\text { phosphohydrolase }\end{array}$ & $(+)$ & $(+)$ & + & + \\
\hline \multicolumn{5}{|l|}{ API 20NE system* } \\
\hline Nitrate reduction & - & + & - & + \\
\hline Caprate & - & - & + & - \\
\hline Adipate & + & + & - & + \\
\hline Malate & + & + & - & + \\
\hline Citrate & - & + & - & + \\
\hline Phenylacetate & - & + & - & + \\
\hline Polar lipids $\dagger$ & $\begin{array}{l}\text { PE, PG, DPG, PL, } \\
\text { AL1, AL2, AL3 }\end{array}$ & $\begin{array}{l}\text { PE, PG, DPG, } \\
\text { AL1, AL2, APL }\end{array}$ & $\begin{array}{l}\text { PE, PG, DPG, } \\
\text { AL1, AL2, APL }\end{array}$ & $\begin{array}{l}\text { PE, PG, DPG, AL1, } \\
\text { AL2, APL1, L1 }\end{array}$ \\
\hline DNA $\mathrm{G}+\mathrm{C}$ content $(\mathrm{mol} \%)$ & 53.1 & 57.3 & 61.8 & 59.4 \\
\hline
\end{tabular}

${ }^{\star}$ Data from this study.

$†$ PE, Phosphatidylethanolamine; PG, phosphatidylglycerol; DPG, diphosphatidylglycerol; AL, unidentified aminolipid; PL, unidentified phospholipid; APL, aminophospholipid; L, unidentified lipid.

B201 ${ }^{\mathrm{T}}$ was $53.1 \mathrm{~mol} \%$, which was a little lower than those of Pusillimonas species (Table 1). Based on physiological, biochemical and phylogenetic properties, strain $\mathrm{B} 201^{\mathrm{T}}$ represents a novel species within the genus Pusillimonas, for which the name Pusillimonas harenae sp. nov. is proposed.

\section{Emended description of the genus Pusillimonas Stolz et al. 2005}

The description of the genus Pusillimonas is as given by Stolz et al. (2005), with the following amendments. DNA $\mathrm{G}+\mathrm{C}$ content is in the range $53.1-61.8 \mathrm{~mol} \%$ and major non-polar fatty acids are $\mathrm{C}_{17: 0}$ cyclo, $\mathrm{C}_{16: 0}$ and summed feature 2 (iso- $\mathrm{C}_{16: 1} \mathrm{I} / \mathrm{C}_{14: 0} 3-\mathrm{OH}$ and/or $\mathrm{C}_{12: 0}$ ALDE).

\section{Description of Pusillimonas harenae sp. nov.}

Pusillimonas harenae (ha.re' nae. L. gen. n. harenae of sand, from where the organism was isolated).
Cells are Gram-negative, strictly aerobic, motile rods (0.5$0.7 \times 0.6-0.9 \mu \mathrm{m})$ with two lateral flagella. Colonies on R2A agar are ivory, convex and round with entire margins. Growth occurs at $15-45{ }^{\circ} \mathrm{C}$ (optimum, $30{ }^{\circ} \mathrm{C}$ ), at $\mathrm{pH} 5.0$ 9.0 (optimum, 6.0-7.5) and in the presence of $0-6 \%(\mathrm{w} / \mathrm{v})$ $\mathrm{NaCl}$ (optimum, 0-3\%). Catalase- and oxidase-positive. Negative for nitrate reduction, indole production, glucose acidification and arginine dihydrolase activities. Positive for assimilation of malic acid and adipic acid, but negative for assimilation of D-glucose, L-arabinose, D-mannose, maltose, D-mannitol, potassium gluconate, $\mathrm{N}$-acetylglucosamine, capric acid, trisodium citrate and phenylacetic acid. Urea is hydrolysed. Aesculin and gelatin are not hydrolysed. Esterase (C4), esterase lipase (C8), leucine arylamidase, valine arylamidase, cystine arylamidase and acid phosphatase activities are present, but not lipase (C14), $\alpha$-galactosidase, $\beta$-galactosidase, $\beta$-glucuronidase, $\alpha$-glucosidase, $\beta$-glucosidase, $N$-acetyl- $\beta$-glucosaminidase, $\alpha$-mannosidase or $\alpha$-fucosidase. Weak enzymic activities 
Table 2. Cellular fatty acid compositions (\%) of strain $B 201^{\top}$ and related Pusillimonas species

Strains: 1, strain $\mathrm{B} 201^{\mathrm{T}} ; 2, \quad P$. ginsengisoli KCTC $22046^{\mathrm{T}} ; 3$, P. noertemannii KACC $13183^{\mathrm{T}}$; 4, P. soli $\mathrm{MJ} 07^{\mathrm{T}}$. All data are from this study. Data are expressed as percentages of total fatty acids. Fatty acids amounting to less than $0.5 \%$ in all strains are not shown. Major components $(>5.0 \%)$ are highlighted in bold. tr, Trace amount $(<0.5 \%)$; ECL, equivalent chain-length; - , not detected.

\begin{tabular}{|c|c|c|c|c|}
\hline Fatty acid & 1 & 2 & 3 & 4 \\
\hline \multicolumn{5}{|l|}{ Saturated } \\
\hline $\mathrm{C}_{12: 0}$ & 7.87 & 0.56 & 4.93 & 9.83 \\
\hline $\mathrm{C}_{14: 0}$ & 1.73 & 4.42 & $\operatorname{tr}$ & 0.51 \\
\hline $\mathrm{C}_{15: 0}$ & 0.68 & 0.57 & - & 0.55 \\
\hline $\mathrm{C}_{16: 0}$ & 32.12 & 36.11 & 20.71 & 40.54 \\
\hline $\mathrm{C}_{17: 0}$ & 0.36 & 0.66 & 0.31 & 0.73 \\
\hline $\mathrm{C}_{17: 0}$ cyclo & 35.65 & 31.03 & 22.51 & 31.26 \\
\hline $\mathrm{C}_{18: 0}$ & 0.6 & 0.97 & 2.54 & 2.45 \\
\hline $\mathrm{C}_{19: 0}$ cyclo $\omega 8 c$ & 5.98 & 2.77 & 20.74 & 2.39 \\
\hline$C_{19: 0}$ 10-methyl & - & - & 1.05 & - \\
\hline \multicolumn{5}{|l|}{ Hydroxy } \\
\hline $\mathrm{C}_{12: 0} 2-\mathrm{OH}$ & - & - & 3.26 & - \\
\hline $\mathrm{C}_{18: 1} 2-\mathrm{OH}$ & - & - & 1.64 & - \\
\hline \multicolumn{5}{|l|}{ Unsaturated } \\
\hline $\mathrm{C}_{18: 1} \omega 7 c$ & 2.22 & 6.71 & 2.40 & 0.50 \\
\hline $\mathrm{C}_{20: 2} \omega 6,9 c$ & $\operatorname{tr}$ & $\operatorname{tr}$ & 0.58 & - \\
\hline \multicolumn{5}{|l|}{ Branched } \\
\hline anteiso- $\mathrm{C}_{17: 1} \mathrm{~A}$ & - & - & 0.84 & - \\
\hline \multicolumn{5}{|c|}{ Summed features ${ }^{\star}$} \\
\hline 2 & 8.77 & 8.45 & 11.16 & 8.04 \\
\hline 3 & 1.79 & 6.68 & 3.68 & 2.11 \\
\hline
\end{tabular}

${ }^{*}$ Summed features represent groups of two or three fatty acids that cannot be separated by GLC with the MIDI system. Summed feature 2 contains $\mathrm{C}_{14: 0} 3-\mathrm{OH}$, iso- $\mathrm{C}_{16: 1} \mathrm{I}$, an unidentified fatty acid with an equivalent chain-length of 10.928 and/or $\mathrm{C}_{12: 0}$ ALDE. Summed feature 3 contains a mixture of $\mathrm{C}_{16: 1} \omega 7 c$ and/or iso- $\mathrm{C}_{15: 0} 2-\mathrm{OH}$.

are observed for alkaline phosphatase, trypsin, $\alpha$-chymotrypsin and naphthol-AS-BI-phosphohydrolase. The major cellular polar lipids are PG, DPG, PE, an unidentified phospholipid and three aminolipids. The major cellular fatty acids ( $>5 \%$ of the total fatty acids) are $\mathrm{C}_{17: 0}$ cyclo, $\mathrm{C}_{16: 0}$, summed feature 2 (iso- $\mathrm{C}_{16: 1} \mathrm{I}_{1 / \mathrm{C}_{14: 0}} 3-\mathrm{OH}$ and/or $\left.\mathrm{C}_{12: 0} \mathrm{ALDE}\right), \mathrm{C}_{12: 0}$ and $\mathrm{C}_{19: 0}$ cyclo $\omega 8 c$.

The type strain is $\mathrm{B} 201^{\mathrm{T}}\left(=\mathrm{KACC} 14927^{\mathrm{T}}=\mathrm{JCM} 16917^{\mathrm{T}}\right.$ ), isolated from beach sand from the Taean coast in South Korea. The DNA G+C content of the type strain is $53.1 \mathrm{~mol} \%$ (HPLC).

\section{Acknowledgements}

This work was carried out with the support of the Technology Development Program for Agriculture and Forestry (TDPAF) of the Ministry for Agriculture, Forestry and Fisheries and the National Research Foundation of Korea grant (2009-0071880) of the Korean Government (MEST), Republic of Korea.

\section{References}

Chun, J., Lee, J. H., Jung, Y., Kim, M., Kim, S., Kim, B. K. \& Lim, Y. W. (2007). EzTaxon: a web-based tool for the identification of prokaryotes based on 16S ribosomal RNA gene sequences. Int J Syst Evol Microbiol 57, 2259-2261.

Felsenstein, J. (2002). PHYLIP (phylogeny inference package) version 3.6a. Distributed by the author. Department of Genome Sciences, University of Washington, Seattle, USA.

Gomori, G. (1955). Preparation of buffers for use in enzyme studies. Methods Enzymol 1, 138-146.

Jeon, C. O., Park, W., Ghiorse, W. C. \& Madsen, E. L. (2004). Polaromonas naphthalenivorans sp. nov., a naphthalene-degrading bacterium from naphthalene-contaminated sediment. Int J Syst Evol Microbiol 54, 93-97.

Jin, H. M., Lee, H. J., Kim, J. M., Park, M. S., Lee, K. \& Jeon, C. O. (2011). Litorimicrobium taeanense gen. nov., sp. nov., isolated from a sandy beach. Int J Syst Evol Microbiol 61, 1392-1396.

Jung, J. Y., Kim, J. M., Jin, H. M., Kim, S. Y., Park, W. \& Jeon, C. O. (2011). Litorimonas taeanensis gen. nov., sp. nov., isolated from a sandy beach. Int J Syst Evol Microbiol 61, 15341538.

Kahng, H.-Y., Chung, B. S., Lee, D.-H., Jung, J.-S., Park, J. H. \& Jeon, C. O. (2009). Cellulophaga tyrosinoxydans sp. nov., a tyrosinaseproducing bacterium isolated from seawater. Int J Syst Evol Microbiol 59, 654-657.

Kim, J. M., Le, N. T., Chung, B. S., Park, J. H., Bae, J.-W., Madsen, E. L. \& Jeon, C. O. (2008). Influence of soil components on the biodegradation of benzene, toluene, ethylbenzene, and $o_{-}^{-}, m-$, and p-xylenes by the newly isolated bacterium Pseudoxanthomonas spadix BD-a59. Appl Environ Microbiol 74, 7313-7320.

Kim, J. M., Lee, S. H., Jung, J. Y. \& Jeon, C. O. (2010a). Marinobacterium lutimaris sp. nov., isolated from a tidal flat. Int $J$ Syst Evol Microbiol 60, 1828-1831.

Kim, J. M., Jung, J. Y., Chae, H. B., Park, W. \& Jeon, C. O. (2010b). Hwanghaeicola aestuarii gen. nov., sp. nov., a moderately halophilic bacterium isolated from a tidal flat of the Yellow Sea. Int J Syst Evol Microbiol 60, 2877-2881.

Komagata, K. \& Suzuki, K. (1987). Lipid and cell-wall analysis in bacterial systematics. Methods Microbiol 19, 161-207.

Lee, M., Woo, S.-G., Chae, M. \& Ten, L. N. (2010). Pusillimonas soli sp. nov., isolated from farm soil. Int J Syst Evol Microbiol 60, 23262330.

Lee, S. H., Shim, J. K., Kim, J. M., Choi, H.-K. \& Jeon, C. O. (2011). Henriciella litoralis sp. nov., isolated from a tidal flat, transfer of Maribaculum marinum Lai et al. 2009 to the genus Henriciella as Henriciella aquimarina nom. nov. and emended description of the genus Henriciella. Int J Syst Evol Microbiol 61, 722-727.

Lu, S., Park, M., Ro, H.-S., Lee, D. S., Park, W. \& Jeon, C. O. (2006). Analysis of microbial communities using culture-dependent and culture-independent approaches in an anaerobic/aerobic SBR reactor. J Microbiol 44, 155-161.

Minnikin, D. E., Patel, P. V., Alshamaony, L. \& Goodfellow, M. (1977). Polar lipid composition in the classification of Nocardia and related bacteria. Int J Syst Bacteriol 27, 104-117.

Park, M., Ryu, S. H., Vu, T. H., Ro, H. S., Yun, P. Y. \& Jeon, C. O. (2007). Flavobacterium defluvii sp. nov., isolated from activated sludge. Int J Syst Evol Microbiol 57, 233-237.

Rosselló-Mora, R. \& Amann, R. (2001). The species concept for prokaryotes. FEMS Microbiol Rev 25, 39-67. 
Smibert, R. M. \& Krieg, N. R. (1994). Phenotypic characterization. In Methods for General and Molecular Bacteriology. pp. 607-654. Edited by P. Gerhardt, R. G. E. Murray, W. A. Wood \& N. R. Krieg. Washington, DC: American Society for Microbiology.

Srinivasan, S., Kim, M. K., Sathiyaraj, G., Kim, Y. J. \& Yang, D. C. (2010). Pusillimonas ginsengisoli sp. nov., isolated from soil of a ginseng field. Int J Syst Evol Microbiol 60, 1783-1787.

Stolz, A., Bürger, S., Kuhm, A., Kämpfer, P. \& Busse, H. J. (2005). Pusillimonas noertemannii gen. nov., sp. nov., a new member of the family Alcaligenaceae that degrades substituted salicylates. Int J Syst Evol Microbiol 55, 1077-1081.

Tamaoka, J. \& Komagata, K. (1984). Determination of DNA base composition by reverse-phase high-performance liquid chromatography. FEMS Microbiol Lett 25, 125-128.

Thompson, J. D., Higgins, D. G. \& Gibson, T. J. (1994). ClusTAL W: improving the sensitivity of progressive multiple sequence alignment through sequence weighting, position-specific gap penalties and weight matrix choice. Nucleic Acids Res 22, 4673-4680. 